\title{
PENGARUH STATUS SOSIAL EKONOMI ORANGTUA DAN SIKAP BERWIRAUSAHA TERHADAP INTENSI BERWIRAUSAHA MAHASISWA PENDIDIKAN EKONOMI UNESA
}

\author{
Nanda Oktafiani Cornelia Burnama \\ Program Studi S1 Pendidikan Ekonomi, Fakultas Ekonomi, Universitas Negeri Surabaya \\ e-mail : nandaburnama@mhs.unesa.ac.id \\ Dhiah Fitrayati. S.Pd., M.E. \\ Program Studi S1 Pendidikan Ekonomi, Fakultas Ekonomi, Universitas Negeri Surabaya \\ e-mail :dhiahfitrayati@gmail.com
}

\begin{abstract}
Abstrak
Pengkajian data memiliki tujuan untuk mengetahui pengaruh status sosial orangtua terhadap intensi berwirausaha , pengaruh sikap berwirausaha terhadap intensi berwirausaha serta pengaruh status sosial ekonomi orangtua dan sikap berwirausaha pada niat berwirausaha. Jenis pengkajian data adalah kuantitatif dengan obyek penelitian mahasiswa jurusan pendidikan ekonomi 2016 unesa. Pengambilan data dilakukan dengan penyebaran angket pada 178 mahasiswa. Proses telaah menggunakan uji analisis regresi linier berganda. Hasil dari pengkajian ini menunjukkan bahwa variabel status sosial ekonomi orangtua berpengaruh negatif dan signifikan terhadap variabel intensi berwirausaha mahasiswa. Sedangkan variabel sikap berwirausaha memiliki pengaruh positif dan signifikan terhadap variabel intensi berwirausaha. Secara simultan, kedua variabel ini juga dinyatakan memiliki pengaruh yang signifikan terhadap intensi berwirausaha.
\end{abstract}

Kata kunci : Status Sosial Ekonomi Orangtua , Sikap Berwirausaha, Intensi Berwirausaha

\section{Abstract}

This study aims to determine the effect of parental social status on entrepreneurial intentions, the influence of entrepreneurial attitudes on entrepreneurial intentions and the influence of parental socioeconomic status and entrepreneurial attitudes on entrepreneurial intentions. This type of research is a quantitative study with the object of research students majoring in economic education in 2016 Unesa. Data was collected by distributing questionnaires to 178 students. Data processing in this study uses multiple linear regression analysis test. The results of this study indicate that the parent's socioeconomic status variable has a negative and significant effect on the student entrepreneurship intention variable. While the entrepreneurship attitude variable has a positive and significant effect on entrepreneurship intention variables. Simultaneously, these two variables are also stated to have a significant influence on entrepreneurial intentions.

\section{Keywords: Parents' Socio-Economic Status, Entrepreneurial Attitude, Entrepreneurial Intention}

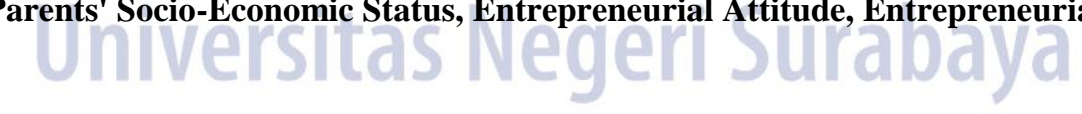

\section{PENDAHULUAN}

Di era globalisasi saat ini tingkat ppengangguran menjadi salah satu yang cukup pantas menyita perhatian. Pengangguran dapat dikatakan sebagai keadaan ketika seseorang yang belum bekerja tidak dapat pekerjaan dikarenakan ketidaksesuaian jumlah lapangan pekerjaan yang sedikit. salah satu hal yang dapat mempengaruhi pasar tenaga kerja adalah ketidaksesuaian orang yang mencari kerja dengan lowongan yang disediakan. Untuk mengatasi hal tersebut, alternatif yang dapat dipilih adalah dengan membuka lapangan pekerjaan sendiri dan menjadi wirausaha. Naiknya tingkat wirausahawan di Indonesia dapat berdampak pada tingkat pengangguran yang menurun(Maisaroh dan Sukemi, 2011).

Oleh sebab itu, di era globalisasi saat ini berbagai pihak termasuk lembaga lembaga pendidikan menganggap penting pendidikan kewirausahaan. Universitas Negeri Surabaya 
sebagai salah satu pemeran penting dalam pendidikan juga memiliki andil dalam penanaman jiwa kewirausahaan untuk mahasiswa. Hal ini terbukti dengan tersedianya fasilitas berupa mata kuliah kewirausahaan yang diajarkan di bangku perkuliahan khususnya di fakultas ekonomi dengan harapan mahasiswa fakultas ekonomi memiliki intensi dalam berwirausaha.

Menurut Ajzen (1991) dalam Theory Planned of Behaviour dijelaskan niata seseorang adalah sesuatu yang menjadi perantara penyebab terjadinya suatu tindakan seseorang, variabel lainnya yang dapat dipengaruhi oleh 3 faktor yaitu : 1) sikap berwirausaha ; 2) norma subyektif ( faktor eksternal ); 3) efikasi diri.

Sikap berwirausaha adalah sesuatu yang ditunjukkan seseorang sebagai bentuk reaksi terhadap suatu hal. Sikap berwirausaha ini menentukan sikap seseorang dalam memulai atau menjalankan bisnis. Dari sikap berwirausaha dapat diketahui bagaimana seseorang itu mengatasi masalah serta kendala pada usaha nya. Menurut Yang (2013) sikap berwirausaha merupakan salah satu prediktor kuat untuk niat berwirausaha.

Berdasarkan hasil observasi di jurusan pendidikan ekonomi, fakultas ekonomi, mahasiswa angkatan 2016 telah mendapat mata kuliah kewirausahaan yang mana mewajibkan mahasiswa untuk melakukan praktek kewirausahaan. Dari hal tersebut, dapat disimpulkan bahwa hampir keseluruhan mahasiswa telah melakukan kegiatan wirausaha. Peneliti kemudian melakukan wawancara tidak terstruktur kepada mahasiswa untuk mengetahui jenis usaha apa saja yang dipilih mahasiswa untuk praktek kewirausahaan mereka dan diketahui bahwa setiap mahasiswa memiliki jenis usaha yang berbeda beda sehingga tidak ada yang sama satu sama lain. Dari hal tersebut dapat diketahui juga bahwa mahasiswa memiliki inovasi dan kreativitas dalam memulai usaha. Akan tetapi walaupun mahasiswa jurusan pendidikan ekonomi telah melakukan kegiatan kewirausahaan bahkan memiliki inovasi dan kreatifitas untuk memulai usaha akan tetapi sebagian besar mengaku tidak ingin melanjutkan usaha yang mereka mulai. Variabel diatas menarik peneliti untuk mencari tahu lebih jauh.

Selain sikap berwirausaha, faktor lain yang dikatakan bisa mempengaruhi niat untuk bertindak oleh seseorang adalah norma subyektif (faktor eksternal ). Norma subyektif adalah keyakinan kondisi disekitar individu yang dapat mempengaruhi sikap seseorang. Norma subyektif meliputi kondisi lingkungan sekitar seperti keluarga, teman, dosen dan lainnya. Menurut (Ramayah dan Harun (2005) status sosial ekonomi orangtua termasuk dalam hal yang dapat digunakan untuk mengukur norma subyektif. Menurut Soekanto (2013) status sosial ekonomi adalah peran yang diemban oleh individu yang berkaitan erat dengan kehidupan dalam lingkungan bermasyarakat baik dari segi tingkat pergaulan, pencapaian hingga hak dan kewajiban. Status sosial ekonomi orang tua dapat mempengaruhi tinggi rendahnya intensi berwirausaha mahasiswa. Soetjiningsih dalam Thohir (2016) mengatakan status sosial ekonomi orangtua yang semakin mapan maka berpengaruh terhadap munculnya niat seseorang

Berdasarkan hasil observasi, status sosial ekonomi orangtua mahasiswa jurusan pendidikan ekonomi khususnya angkatan 2016 dapat dikatakan baik. Pada saat dilakukan wawancara tidak terstruktur kepada beberapa mahasiswa di jurusan pendidikan ekonomi 2016, mahasiswa tersebut mengatakan bahwa baik tingkat pendapatan, pekerjaan maupun pendidikan orangtua mereka ada pada golongan menegah ke atas. Akan tetapi, walaupun pendapatan orang tua tinggi, minat mahasiswa untuk berwirausaha masih dikatakan rendah. Fakta tersebut bertentangan dengan hasil penelitian Thohir (2016) yang mengungkapkan dalam penelitiannya bahwa jika variabel bebas pada penelitian ini bernilai tinggi bisa berpengaruh pada niat seseorang dalam berwirausaha. sehingga peneliti tertarik untuk meneliti variabel tersebut.

Menurut wahyono (2013) intensi dapat diartikan sebagai kebulatan tekad seseorang untuk melakukan sesuatu. Dalam teori perilaku terencana atau dikenal dengan Theory Planned of Behaviour (Ajzen, 1991), diketahui bahwa intensi atau niat seseorang dapat dipengaruhi oleh beberapa hal. Teori ini adalah revolusi dari teori tindakan beralasan

Menurut Ajzen (1991) niat dapat dianggap sebagai bentuk motivasi mencapai sesuatu. niat ini dapat menjelaskan sebesar apa upaya seseorang untuk dapat menggapai apa yang diinginkan dan akan tercermin pada perilaku seseorang tersebut. Intensi yang ada pada penelitian ini adalah niat seseorang dalam 
memulai sesuatu khususnya pada bidang kewirausahaan yang dapat dipengaruhi beberapa faktor yang diungkapkan Ajzen (1991)

Menurut Baron dan Byrne dalam Iskandarsyah dan Andika(2012) norma subyektif adalah perkiraan pemikiran seseorang tentang terjadinya pro dan kontra dilingkungan sekitar .Dukungan dari orang lain yang dimaksud adalah dukungan dari berbagai pihak di sekitar individu misalnya orangtua, teman, guru. Oleh sebab itu, status sosial ekonomi orangtua termasuk di dalam norma subjektif atau faktor ekternal yang dapat mempengaruhi intensi.

Di dalam KBBI istilah status artinya posisi (orang, badan, dan sebagainya) yang ada kaitannya dengan lingkungan masyarakat. Menurut Soekanto(2013) status adalah suatu tempat atau posisi seseorang di dalam suatu kelompok sosial. Menurut Vili(2015) status sosial dapat dianggap sebagai suatu peranan penting dalam masyarakat yang dipegang oleh seseorang. Vili juga membedakan status sosial individu dalam dua aspek yaitu :

1) Aspek statis

Status dianggap suatu variabel pembeda dalam masyarakat

2) Aspek dinamis

Status adalah sesuatu yang punya kaitan erat dengan peranan masyarakat

Dalam penelitian ini , peneliti akan mengikuti aspek statis dimana hanya melihat pada kedudukan orangtua dalam kelompok masyarakat.Menurut Schiffman(2008) untuk mengukur status sosial ekonomi telah di definisikan sebagai berikut :

1) Historis pendidikan orangtua, yang merupakan pendidikan akademik terakhir ayah sebagai kepala keluarga

2) Pekerjaan orangtua, yang merupakan mata pencaharian ayah guna memenuhi kebutuhan keluarga

3) Penghasilan orangtua, yang merupakan pendapatan dari mata pencaharian ayah

Sikap menurut Slameto(2010) adalah kesediaan seseorang untuk merespon terhadap suatu situasi. Lebih lanjut dijelaskan bahwa sikap menggambarkan sesuatu yang dipahami, dan sikap akan mencerminkan pilihan seseorang untuk bertindak. Menurut assael dalam Iskandarsyah dan Andika(2012) sikap diartikan sebagai kecenderungan yang dipelajari untuk obyek dapat memberikan respon secara konsisten baik respon suka atau tidak suka. Menurut Ajzen (1991) sikap berwirausaha adalah tindakan atau tingkah laku dan mengacu pada seperti apa pandangan seseorang untuk memiliki penilaian yang menguntungkan atau tidak beralasan atau penilaian terhadap perilaku yang dipertanyakan. Dari uraian beberapa tokoh diatas maka dapat diambil intisari bahwa sikap adalah hal yang dipelajari untuk melihat cara objek memberi dan menerima respon terhadap situasi baik yang disuka ataupun tidak disuka.

Sikap berwirausaha menurut Iskandarsyah dan Andika (2012) adalah tendensi individu untuk berperilaku secara spontan dalam menangani ancaman yang akan dihadapi dalam suatu bisnis. Tony(2008) mengungkapkan bahwa aspek pokok dalam sikap berwirausaha ada 2 yaitu kepercayaan diri seseorang bahwa ketika memilih untuk memperlihatkan atau tidak perilaku tertentu pasti berimbas pada hasilnya dan aspek pemahamanseseorang tentang suatu tindakan yang bisa berwujud pendapat individu yang kaitannya belum tentu sesuai dengan fakta dilapangan .Sikap berwirausaha yang ada berpedoman pada pendapat Ajzen (1991)

Menurut Gaddam(2008) indikator dalam mengukur sikap berwirausaha adalah sebagai berikut :

1) Tertarikdengan peluang usaha

2) Berfikir kreatif dan inovatif

3) Pandangan positif mengenai kegagalan usaha

4) Memiliki jiwa kepemimpinan dan tanggung jawab

5) Sukamenghadapi risiko dan tantangan

Pada titik akhir penelitian ini akan berusaha mengungkap seberapa dalam pengaruh variabel variabel bebas baik variabel status sosial ekonomi orangtua maupun variabel sikap berwirausaha pada niat berwirausaha seseorang baik secara terpisah maupun bersamaan

\section{METODE PENELITIAN}

Jenis pengkajian ini adalah kajian kuantitatif dengan populasi mahasiswa jurusan pendidikan ekonomi 2016 UNESA. Pengumpulan sampel pada penelitian ini menggunakan metode Random Sampling , dimana pengambilan dilakukan secara acak dengan asumsi semua responden dalam populasi punya kesempatan yang sama untuk menjadi responden. Responden yang digunakan 
berjumlah 178 orang yang diambil dari 4 prodi dalam jurusan pendidikan ekonomi

Penelitian yang dilakukan melakukan pengumpulan data dengan observasi dan penyebaran angket kepada responden. Sebelum instrumen disebar, peneliti melakukan proses validitas dan reliabilitas terlebih dahulu untuk mengetahui keakuratan dari alat uji yang dipakai

Proses analisis yang digunakan dalam data pada penelitian ini adalah uji analisis regresi linier berganda untuk melihat sejauh mana pengaruh variabel bebas status sosial ekonomi orangtua dan sikap berwirausaha terhadap variabel terikat intensi berwirausaha

Uji analisis regresi linier berganda digunakan dengan pertimbangan terdapat lebih dari satu variabel bebas yaitu variabel Status Sosial Ekonomi Orang tua ( X1 ) dan Sikap berwirausaha ( $\mathrm{X} 2$ ) yang di duga mempengaruhi variabel terikat Intensi berwirausaha ( $\mathrm{Y}$ ). Dalam persamaan, uji analisis regresi linier berganda dapat dinyatakan sebagai berikut :

$$
\begin{aligned}
& \mathrm{Y}=\mathrm{a}+b_{1} X_{1}+b_{2} X_{2}+\varepsilon \\
& \text { Keterangan : } \\
& \mathrm{Y} \quad=\text { Intensi berwirausaha mahasiswa } \\
& \mathrm{a} \quad=\text { konstanta regresi } \\
& \mathrm{b} \quad=\text { koefisien regresi } \\
& \mathrm{X} 1=\text { status sosial ekonomi orang tua } \\
& \mathrm{X} 2=\text { Sikap berwirausaha } \\
& \varepsilon \quad=\text { faktor lain diluar penelitian }
\end{aligned}
$$

\section{HASIL DAN PEMBAHASAN}

\section{Pengaruh status sosial ekonomi terhadap} intensi berwirausaha

Berkaca pada hasil pengolah data pada hipotesis dengan variabel status sosial ekonomi orangtua terhadap variabel intensi berwirausaha mahasiswa jurusan pendidikan ekonomi memiliki pengaruh secara signifikan . Hasil analisis dapat dibuktikan dengan nilai signifikansi variabel status sosial ekonomi orangtua lebih kecil dari alpha $(0.002<0.05)$. Dari hasil uji tersebut dapat diketahui bahwa mahasiswa setuju jika status sosial ekonomi orangtua akan berpengaruh pada intensi berwirausaha mahasiswa

Melalui uji hipotesis juga dapat diketahui bahwa variable bebas status sosial ekonomi orangtua memiliki pengaruh negatif terhadap variabel intensi berwirausaha. Hal ini terlihat dari nilai Unstandardized Coefficients Betha dari variabel status sosial ekonomi orangtua sebesar -0,128 yang artinya semakin tinggi status sosial ekonomi orangtua maka intensi berwirausaha mahasiswa akan semakin rendah. Begitu juga sebaliknya , semakin rendah status sosial ekonomi orangtua maka semakin tinggi niat berwirausaha mahasiswa.

Hasil penelitian ini sejalan dengan penelitian milik (Reilly, M. D., \& Carsrud, A. L.Krueger, N. F. Jr., 2000) yang mengatakan bahwa norma subyektif yang berkaitan dengan status sosial ekonomi orangtua memiliki pengaruh negatif terhadap niat seseorang berwirausaha. Akan tetapi hasil pengolahan data pada telaah memiliki kecondongan negatif dengan penelitian terdahulu yang mengatakan bahwa status sosial ekonomi orangtua memiliki kecondongan positif terhadap intensi orangtua yang artinya semakin mapan ekonomi orangtua maka intensi berwirausaha akan semakin meningkat (Thohir, 2016). Perbedaan ini dapat dijelaskan oleh peneliti dengan pertimbangan perbedaan waktu, lokasi dan objek penelitian. Hal ini dapat disimpulkan dari hasil pada angket dimana sebanyak $63,9 \%$ responden menyadari bahwa dukungan orangtua sangat penting untuk memilih sebuah usaha. Hal ini dikuatkan dengan $39,6 \%$ responden menganggap kondisi ekonomi keluarga menjadi faktor penting untuk membuka usaha dimana sebesar $27,1 \%$ responden memiliki pendapatan orangtua $<\operatorname{Rp} 1.500 .000$.

\section{Pengaruh sikap berwirausaha terhadap} intensi berwirausaha

Sikap berwirausaha dijelaskan pada hasil uji hipotesis, diketahui bahwa sikap berwirausaha memiliki pengaruh signifikan terhadap intensi berwirausaha. Hal ini dapat dibuktikan dengan nilai signifikansi variabel sikap berwirausaha lebih kecil dari alpha ( 0.000 $<0.05$ ) yang artinya Ha diterima. Dari data tersebut dapat dijelaskan bahwa mahasiswa setuju sikap berwirausaha yang dimiliki mahasiswa akan berpengaruh pada intensi berwirausaha.

Hasil pemrosesan data juga menunjukkan dari hasil uji hipotesis yang sudah dilakukan adalah variabel sikap berwirausaha mempunyai pengaruh berbanding lurus terhadap variabel intensi berwirausaha. Hal ini dapat diketahui dari nilai Unstandardized Coefficients 
Betha dari variabel sikap berwirausaha sebesar 0,776 yang artinya semakin naik nilai sikap berwirausaha mahasiswa maka kecenderungan niat juga akan naik.

Hasil ini didukung oleh penelitian Nurul Islami (2014) yang mengatakan bahwa sikap berwirausaha bisa melakukan sumbangan positif terhadap kemungkinan munculnya niat kewirausahaan mahasiswa. Sama halnya dengan penelitian ini , Iskandarsyah dan Andika (2012) mengungkapkan bahwa secara simultan maupun parsial variabel sikap berwirausaha dapat mempengaruhi variabel intensi berwirausaha secara signifikan. Dari data yang diperoleh peneliti, sebesar $57,6 \%$ responden tertarik membuka usaha sendiri. Hal ini dipengaruhi beberapa indikator dalam sikap berwirausaha diantaranya sebesar $55,6 \%$ responden dapat mengembangkan ide ide usaha baru, sedangkan sebesar $42,4 \%$ responden menyatakan memiliki jiwa kepemimpinan yang kuat. Hal ini dikuatkan dengan pendapat dari $53,5 \%$ responden yang mengatakan bahwa resiko pada bisnis merupakan hal yang biasa.

Maka dapat ditarik intisari bahwa hasil telaah menunjukkan kesesuaian dengan teori yang diungkapkan oleh (Ajzen, 1991) yang mengatakan bahwa sikap berwirausaha merupakan salah satu variabel penting yang memiliki dampak pada intensi pada seseorang

\section{Pengaruh status sosial ekonomi orangtua dan sikap berwirausaha terhadap intensi berwirausaha \\ Jika melihat proses serta hasil uji} hipotesis yang dilakukan, dapat diketahui variabel status sosial ekonomi orangtua dan variabel sikap berwirausaha secara simultan mempunyai pengaruh yang signifikan terhadap variabel intensi berwirausaha. $\mathrm{Hal}$ ini dapat dilihat dari nilai signifikansi sebesar 0.000 yang artinya mahasiswa setuju jika kedua variabel secara bersamaan punya pengaruh terhadap variabel intensif berwirausaha. Walaupun sama sama berpengaruh, namun variabel status sosial ekonomi orangtua punya pengaruh yang dapat dikatakan kuat jika dibandingkan dengan variabel sikap berwirausaha. Hal ini dapat dilihat dari nilai Unstandardized Coefficients Betha dari kedua variabel dimana variabel status sosial ekonomi memiliki nilai 0.002 sedangkan variabel sikap berwirausaha memiliki nilai 0.000 .
Hasil penelitian ini tidak sealiran dengan milik Vemmy (2012) yang mengatakan bahwa norma subjektif yang berkaitan erat dengan status sosial ekonomi orangtua memang berpengaruh terhadap intensi berwirausaha , akan tetapi pengaruhnya tidak lebih besar dari sikap berwirausaha dan efikasi diri. Hal serupa juga diungkapkan dalam penelitian Nurul Islami (2014) yang bahkan mengatakan bahwa hanya sikap berwirausaha dan efikasi diri yang berpengaruh secara signifikan terhadap intensi berwirausaha sedangkan status sosial ekonomi orangtua tidak memiliki pengaruh secara langsung terhadap intensi berwirausaha.

Pada penelitian ini, koefisien determinasi ganda dapat diketahui dari nilai pada tabel Adjusted R Square. Pada proses pengolahan data juga jika diketahui nilai $\mathrm{R}$ Square sebesar 0,557. Artinya variabel status sosial ekonomi orangtua dan sikap berwirausaha dapat menjelaskan variabel intensi berwirausaha sebesar 55,7\% sedangkan sisanya sebesar $44,3 \%$ dijelaskan oleh variabel lain diluar penelitian.

\section{PENUTUP}

Simpulan

Berdasarkan hasil telaah yang telah dilakukan, maka dapat diambil substansi bahwa status sosial ekonomi orangtua punya pengaruh signifikan dan berbanding terbalik terhadap intensi berwirausaha mahasiswa jurusan pendidikan ekonomi 2016 unesa. Sedangkan sikap berwirausaha mempunyai pengaruh signifikan dan berbanding lurus terhadap intensi berwirausaha mahasiswa jurusan pendidikan ekonomi 2016 unesa. Lebih lanjut dijabarkan dalam penelitian ini adalah bahwa status sosial ekonomi orangtua dan sikap berwirausaha secara bersama memiliki pengaruh yang signifikan terhadap intensi berwirausaha jurusan pendidikan ekonomi 2016 unesa

\section{Saran} Berdasarkan hasil penelitian,
peneliti dapat memberikan masukkan
bahwa karena penelitian ini memilih
mahasiswa jurusan pendidikan ekonomi 2016
unesa sebagai objek penelitian sehingga saran
yang diberikan adalah jika melakukan penelitian
serupa, peneliti lain bisa memperluas jangkauan
responden agar hasil yang didapatkan bisa
bervariasi selain itu, dalam penelitian ini untuk
faktor pendorong intensi berwirausaha hanya
menggunakan 2 variabel. Saran yang diberikan
adalah peneliti lain bisa menggunakan faktor
pendorong lain sebagai variabel untuk diteliti 


\section{DAFTAR PUSTAKA}

Ajzen, I. (1991). The Theory of Planned Behavior, 211, 179-211.

Arikunto, S. (2013). Prosedur Penelitian: Suatu Pendekatan Praktik (Cetakan Ke). Jakarta: PT RINEKA CIPTA.

Astuti yuli, W. (2016). Pengaruh kondisi sosial ekonomi keluarga terhadap minat belajar siswa SMK YPKK 3 sleman. Univeristas Negeri Yogyakarta.

BPS. (2014). Klasifikasi Baku Jabatan Indonesia. Jakarta.

Bungin, B. (2014). Metodologi Penelitian Kuantitaif (Edisi Kedu). Jakarta: Kencana Prenada Media Group.

Gaddam, S. (2008). Identifying the Relatinship Between Behavioral Motives and Entrepreneurial Intentions: An Empirical Study Based Participations of Business Management Students. The Icfaian Journal of Management Research, 7.

Ghozali, I. (2016). Desain Penelitian Kuantitatif dan Kualitatif. Semarang: Yoga Pratama.

Iskandarsyah dan Andika. (2012). Analisis Pengaruh Sikap, Norma Subyektif Dan Efikasi Diri Terhadap Intensi Berwirausaha Pada Mahasiswafakultas Ekonomi Universitas Syiah Kuala (Studi Pada Mahasiswa Fakutas Ekonomi Universitas Syiah Kuala).

Maisaroh dan Sukemi. (2011). PEMBERDAYAAN MASYARAKAT MELALUI PENGEMBANGAN BUDAYA KEWIRAUSAHAAN UNTUK MENGURANGI PENGANGGURAN DAN KEMISKINAN, 4, 23-33.

Nurhasanah, S. (2016). Praktikum Statistika 2 untuk ekonomi dan bisnis : aplikasi dengan Ms Excel dan SPSS. Jakarta: Salemba Empat.

Nurul Islami, N. (2014). Pengaruh Sikap Kewirausahaan, Norma Subjektif dan Efikasi Diri terhadap Perilaku Berwirausaha Mahasiswa melalui Intensi Berwirausaha, 3(1), 5-21.

Paulina, I. (2012). Faktor pendukung intensi berwirausaha pada mahasiswa. Jurnal Dinamika Manajemen, 3(1), 1-10.

Prakoso, A. F. (2018). Modul Pembuatan Kuisioner Online dengan Google form dan Uji Validitas, Reliabilitas, Transformasi skor menjadi Skala Berbasis SRS dengan Software Soland. Surabaya: Pusat Studi Pendidikan Ekonomi dan Bisnis Fakultas Ekonomi Unesa.

Ramayah dan Harun. (2005). Entrepreneurial Intention Among the Studen of Universiti Sains Malaysia (USM). International. Journal of Management and Entrepreneurship, 1, 8-20.

Reilly, M. D., \& Carsrud, A. L.Krueger, N. F. Jr. (2000). Competing models of entrepreneurial intentions. Journal of Business Venturing, 15, 411-432. https://doi.org/http://doi.org/dq9tqw

Saifi, S., \& Tariq Mehmood. (2011). Effect Of
Socioeconomic Status On Student Achievement. International Journal of Social Science and Education, 1(2 April 2011).

Schiffman. (2008). Perilaku Konsumen (Edisi ke 7). Jakarta: PT Indeks.

Slameto. (2010). Belajar dan Faktor Faktor yang Mempengaruhinya (cetakan 5). Jakarta: PT RINEKA CIPTA.

Soekanto, S. (2013). Sosiologi suatu pengantar (Edisi Revi). Jakarta: PT Raja Grafindo Persada.

Sugihartono. (2015). Psikologi Pendidikan. Yogyakarta: UNY Press.

Sugiyono. (2014). Metode Penelitian Pendidikan: Pendekatan Kuantitatif, Kualitatif, Dan $R \& D$. Bandung: Alfabet.

Suryana, Y. (2011). Kewirausahaan Pendekatan Karakteristik Wirausahawan Sukses. Jakarta: Kencana Prenada Media Group.

Thohir, dkk. (2016). PENGARUH STATUS SOSIAL EKONOMI ORANG TUA, LITERASI EKONOMI DAN PERCAYA DIRI TERHADAP MINAT BERWIRAUSAHA SISWA SMP NEGERI DI KECAMAN TENGIILIS MEJOYO SURABAYA. Jurnal Ekonomi Pendidikan Dan Kewirausahaan, 4(2).

Tony, W. (2008). Kajian Model Empiris Perilaku Berwirausaha UKM DIY dan Jawa tengah. Jurnal Manajemen Dan Kewirausahaan, 10, 93-104.

Tony, W. (2015). INTENSI BERWIRAUSAHA MAHASISWA : PERSPEKTIF PENGAMBILAN RISIKO. Jurnal Siasat Bisnis, 19(2), 109-123.

Vemmy, C. (2012). FAKTOR-FAKTOR YANG MEMPENGARUHI FACTORS AFFECTING ENTREPRENEURIAL INTENTION OF. Jurnal Pendidikan Vokasi, 2(1), 117-126.

wahyono, budi. (2013). pengaruh pendidikan kewirausahaan terhadap niat berwirausaha siswa SMK Negeri 1 Pedan. PPs UNS.

Yang, J. (2013). THE THEORY OF PLANNED BEHAVIOR AND PREDICTION OF ENTREPRENEURIAL INTENTION AMONG CHINESE UNDERGRADUATES. Social Behaviour and Personality, 41(71002112), 367376. 